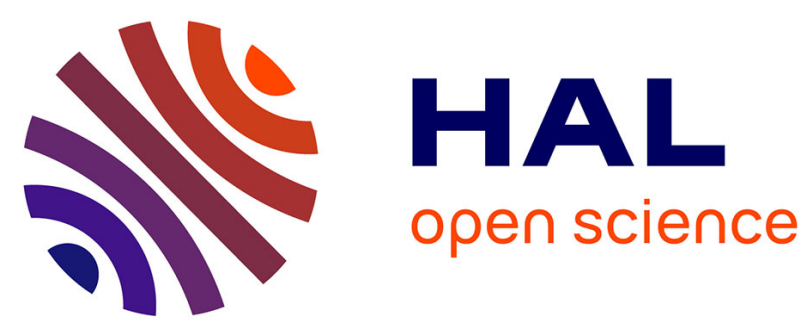

\title{
Complications after pelvic floor repair surgery (with and without mesh): short-term incidence after 1873 inclusions in the French VIGI-MESH registry.
}

Xavier Fritel, Sandrine Campagne-Loiseau, Michel Cosson, Philippe Ferry, Christian Saussine, Jean-Philippe Lucot, Delphine Salet-Lizee, Marie-Line Barussaud, Thomas Boisramé, Caroline Carlier-Guérin, et al.

\section{To cite this version:}

Xavier Fritel, Sandrine Campagne-Loiseau, Michel Cosson, Philippe Ferry, Christian Saussine, et al.. Complications after pelvic floor repair surgery (with and without mesh): short-term incidence after 1873 inclusions in the French VIGI-MESH registry.. BJOG: An International Journal of Obstetrics and Gynaecology, 2019, 10.1111/1471-0528.15956 . inserm-02310221

\section{HAL Id: inserm-02310221 https://www.hal.inserm.fr/inserm-02310221}

Submitted on 10 Oct 2019

HAL is a multi-disciplinary open access archive for the deposit and dissemination of scientific research documents, whether they are published or not. The documents may come from teaching and research institutions in France or abroad, or from public or private research centers.
L'archive ouverte pluridisciplinaire HAL, est destinée au dépôt et à la diffusion de documents scientifiques de niveau recherche, publiés ou non, émanant des établissements d'enseignement et de recherche français ou étrangers, des laboratoires publics ou privés. 
Title page

Complications after pelvic floor repair surgery (with and without mesh): short-term incidence after 1873 inclusions in the French VIGI-MESH registry

Xavier Fritel, 1, 2

Sandrine Campagne-Loiseau, 3

Michel Cosson, 4

Philippe Ferry, 5

Christian Saussine, 6

Jean-Philippe Lucot, 7

Delphine Salet-Lizee, 8

Marie-Line Barussaud, 9

Thomas Boisramé, 10

Caroline Carlier-Guérin, 11

Thomas Charles, 12

Philippe Debodinance, 13

Xavier Deffieux, 14

Anne-Cécile Pizzoferrato, 15

Sandra Curinier, 3

Stéphanie Ragot, 16

Virginie Ringa, 2

Renaud de Tayrac, 17

Arnaud Fauconnier, 18

Institutions

1. Université de Poitiers, INSERM CIC 1402, CHU de Poitiers, Service de gynécologie-obstétrique, Poitiers, France

2. CESP Inserm U1018, Paris, France

3. CHU Estaing, Service de gynécologie-obstétrique, Clermont-Ferrand, France

4. Université de Lille, CHU de Lille, Service de gynécologie-obstétrique, France

5. $\mathrm{CH}$ de La Rochelle, Service de gynécologie-obstétrique, La Rochelle, France

6. Université de Strasbourg, CHU de Strasbourg, Service d'urologie, Strasbourg, France

7. Hôpital Saint-Vincent-de-Paul, Service de gynécologie-obstétrique, Lille, France

8. Groupe Hospitalier Diaconesses-Croix-Saint-Simon, Service de gynécologie, Paris, France

9. CHU de Poitiers, Service de chirurgie viscérale, Poitiers, France

10. CHU de Strasbourg, Service de gynécologie-obstétrique, Strasbourg, France 11. $\mathrm{CH}$ de Châtellerault, Service de gynécologie-obstétrique, Châtellerault, France 12. CHU de Poitiers, Service d'urologie, Poitiers, France 
41 13. $\mathrm{CH}$ de Dunkerque, Service de gynécologie-obstétrique, France

42 14. Université Paris-Sud, APHP Antoine-Béclère, Service de gynécologie-obstétrique,

43 Clamart, France

44 15. CHU de Caen, Service de gynécologie-obstétrique, France

45 16. Université de Poitiers, INSERM CIC 1402, Poitiers, France

46 17. Université de Nîmes, CHU Carémeau, Service de gynécologie-obstétrique,

$47 \quad$ Nîmes, France

48 18. UVSQ, CHI Poissy-Saint-Germain, Service de gynécologie-obstétrique, Poissy, France

Correspondence

52 Prof. Xavier Fritel, Service de Gynécologie-Obstétrique et Médecine de la

53 Reproduction, 2 rue de la Milétrie, CHU de Poitiers, F-86000 Poitiers, France.

$54+33549443$ 360. xavier.fritel@univ-poitiers.fr

55

56 Running title: Complications after pelvic floor repair surgery

57

58

Word count: 3441

59 


\section{Abstract}

Objective: Assess the short-term incidence of serious complications of surgery for urinary incontinence or pelvic organ prolapse

Design: Prospective longitudinal cohort study by using a surgical registry

Setting: 13 public hospitals in France

Population or Sample: 1873 women undergoing surgery between February 2017 and August 2018

Methods: Preliminary analysis of serious complications after a mean 7-month followup (0-18), according to type of surgery. Surgeons reported procedures and complications, which were verified by the hospitals' information systems.

Main Outcome Measures: Serious complication requiring discontinuation of the procedure or subsequent surgical intervention, life-threatening complication requiring resuscitation, or death.

Results: 52 women $(2.8 \%, 95 \% \mathrm{Cl} 2.1-3.6)$ experienced a serious complication during either the surgery, requiring discontinuation of the procedure, or the first months of follow-up, necessitating a subsequent reoperation; one case also required resuscitation; no women died. Of 811 midurethral slings (MUS), 11 were removed in part or totally $(1.4 \%, 0.7-2.3)$, as were 2 of 391 transvaginal meshes $(0.5 \%, 0.1-1.6)$, and 4 of 611 laparoscopically placed mesh implants $(0.7 \%, 0.2-1.5)$. The incidence of serious complications 6 months after the surgical procedure was estimated around $3.5 \%(2.0-5.0)$ after MUS alone, $7.0 \%(2.8-11.3)$ after MUS with prolapse surgery, $1.7 \%(0.0-3.8)$ after vaginal native tissue repair, $2.8 \%(0.9-4.6)$ after transvaginal mesh, and $1.0 \%(0.1-1.9)$ after laparoscopy with mesh.

Conclusions: Early serious complications are relatively rare. Monitoring must be continued and enlarged to assess the long-term risk associated with mesh use and identify its risk factors.

Funding: Agence Nationale de Sécurité du Médicament

Keywords: Mesh, stress urinary incontinence, pelvic organ prolapse, surgery, Iongitudinal study, short-term major complication

Tweetable abstract: Short-term serious complications are rare after surgery for urinary incontinence or pelvic organ prolapse, even with mesh 
Introduction:

Stress urinary incontinence (SUI) and pelvic organ prolapse (POP) are frequent among women older than 50 years and can be functionally disabling. ${ }^{1,2}$ When surgical repair is selected, implanted inert, non-absorbable medical devices (or meshes) are often used. ${ }^{3}$ Numerous manufacturers offer these devices, which differ in the composition of the materials used (polyester, polypropylene, biological, absorbable, etc.), the manufacturing process (knit, non-woven, welded, coated, etc.), or the technique for fastening them (transfixing, or by glue, absorbable thread, nonabsorbent thread, stapled, etc.). The risk of complications may vary with the surgeon's experience, the woman's characteristics, the surgical pathway (vaginal, laparotomic, or laparoscopic, or mixed), the placement technique, and the materials used. $^{4,5}$

The main complications associated with mesh use are exposure or erosion of the material, functional complications, such as pain and urinary obstruction, and their consequences on sexual function (dyspareunia, cessation of intercourse). ${ }^{6,7}$ These complications can have serious functional and psychological repercussions and require surgical revision. The UK regulatory authorities estimate that approximately $4 \%$ of the 100000 midurethral slings (MUS) implanted between 2005 and 2013 have been removed. ${ }^{8}$

Medical implant monitoring cannot estimate either exhaustively or precisely the incidence of complications linked to the use of these devices, because the number and type of surgical procedures involving mesh placement are unknown and due to the probable under-reporting of their later complications. ${ }^{6}$ Some incidents of mesh exposure have been observed more than five years after their placement. ${ }^{9,10}$ Randomised trials based on the best trained, most experienced teams present a risk of underestimating the occurrence of complications that are either rare or associated with surgical malpractice; ${ }^{4} \mathrm{RCT}$ s are not adequately powered to detect rare but serious adverse events.

In 2018 the British government and National Health Service announced the restriction of use of vaginally inserted surgical mesh and recommended high vigilance scrutiny for procedures where there is no alternative to vaginally inserted mesh, procedures offered as alternatives to mesh, and procedures involving abdominally-inserted mesh. ${ }^{11}$

In France, the national medicines agency (Agence Nationale de Sécurité du Médicament et des produits de santé, ANSM) issued a call in 2016 for a surgical registry to collect mesh use in SUI or POP surgery and follow up adverse effects. ${ }^{12}$ Our project, funded by the ANSM, began in 2017. The objective of this first analysis is to describe the data collection methods of VIGI-MESH registry and report the results of its first months of operation. 
The surgeons involved in the randomised PROSPERE trial (comparing the complications of laparoscopic sacropexy and of transvaginal mesh implantation to Already trained and experienced in reporting serious adverse effects (PROSPERE's principal outcome criteria) with a reporting process of proven reliability, they have also demonstrated their recruitment capacity. The outcomes developed for the PROSPERE trial, based on the Clavien-Dindo classification for surgical complications, were again used for the VIGI-MESH registry: ${ }^{13}$ grade III complications were defined by the discontinuation of the surgical procedure (mesh planned but not placed or removed immediately) or by the need for subsequent surgical, endoscopic, or radiological intervention, grade IV by a life-threatening complication, and grade $\mathrm{V}$ by the woman's death. Grade II complications were recorded but not considered serious; they included suture or mesh removal at office visits or bedside, along with any surgical injury repaired during the procedure with no modification (neither an additional surgical incision nor discontinuation of the procedure). As in the PROSPERE trial, subsequent surgery for failure or recurrence of incontinence or prolapse was reported but not considered a complication. ${ }^{4}$ Complications were also described according to the IUGA/ICS classification. ${ }^{14,15}$ Each investigator collected the complications, described them and their management in detail, and graded them. The severity of complications was cross-checked by the first author from operative reports. This analysis considers only serious complications (grade III and above).

The PROSPERE team had an annual volume of around 3000 operations (1300 for SUI and 1700 for POP). Based on PROSPERE's results, we estimated the incidence of serious complications (defined as grade III or higher on the Clavien-Dindo scale) at $4 \%$ a year, or 120 events. ${ }^{4}$

Registration of these surgical procedures began in February 2017. In accordance with French law for studies of usual care (i.e., not involving experimental interventions or treatments), each woman undergoing surgery for SUI, pelvic organ prolapse, or rectal prolapse received thorough written information about the register, was assured that all identifying data would remain confidential, and was asked to consent to the recording of her data and to receiving follow-up questionnaires for the next decade.

Eligible surgical procedures included the placement of midurethral slings (MUS), retropubic (Burch) colposuspension, vaginal repair surgery with or without mesh, abdominal or laparoscopic repair and endoanal surgery. Procedures involving artificial sphincters, balloons and periurethral injections were not included.

All surgeons reported each operation they performed on a specific case report form that collected the woman's characteristics (age, physical status, surgical history, diabetes, smoking status, menopause, and sexual activity) and the surgical procedures used (with or without mesh, manufacturer's name of the mesh and kit, and type of fixation, approach, additional procedures, duration of surgery and coding). The exhaustiveness of the data collection was verified by reviewing the mesh delivery forms (for each patient) from the hospital pharmacies and the surgical procedure codes recorded by each hospital's medical data department.

We used several sources to identify complications: the monitoring of specific surgical procedures for complications by the data departments, surgeons' spontaneous reports, and a questionnaire sent to the women a year later. These annual follow-up 
questionnaires collected information about perceived health and improvement (WHO, EQ5D, and PGI-I questionnaires) and can be considered patient-reported outcomes. Complications were analysed, based on the surgeon's case report forms, the surgical reports, and the women's responses to the one-year follow-up, on a centralised basis.

We planned to describe the surgical procedures and classify them by mesh use (yes/no), approach (vaginal, laparoscopic, or laparotomic), and indication (incontinence or prolapse). A preliminary examination of the first inclusions allowed us to list the principal surgical procedures and the expected complications.$^{16}$ This analysis distinguished five groups: isolated MUS (retropubic, transobturator, or single-incision) with no procedure for prolapse, MUS with surgical treatment of prolapse, transvaginal repair with at least one mesh, vaginal native tissue repair and laparoscopy with mesh. We built a Kaplan-Meier survival curve to represent the incidence of short-term complications by surgical group, according to the dates of the surgery and the complication. For all women, the last date of follow-up for this initial short-term analysis was set at 9 August, 2018. Complications after that date are not considered here. For women with more than one complication, we have considered the first classified as grade III or higher.

Complications are described according to the surgical procedure involved as well as their nature, their management and the interval between the procedure and its occurrence. The incidence of complications associated with MUS procedures was analysed by a multivariate logistic regression that considered the type of MUS (retropubic, transobturator, or single-incision), concomitant hysterectomy and any concomitant procedure for POP. The incidence of complications associated with POP procedures was analysed by considering the surgical group (transvaginal mesh, vaginal native tissue repair or laparoscopy with mesh), concomitant hysterectomy and concomitant MUS. Multivariate analyses were adjusted for age, smoking, and recurrent surgery for IU or POP.

Patients were not involved in the development of the VIGI-MESH registry. No core outcome sets were used. This registry-based study is listed on clinicaltrial.gov (NCT03052985). 
Results:

Between February 2017 and August 2018, the 13 participating surgical centres prospectively included 1887 women (9-365 per centre). The procedures for 14 women did not correspond to the predefined surgical groups: 4 Altemeier or Delorme procedures, 1 laparotomic Burch colposuspension, 2 laparoscopy without mesh, and 8 laparotomies with mesh. These were not included in the analysis. We estimated that $79 \%$ of the eligible patients consented to participate (Table S1).

The index surgery (at inclusion) was for SUI alone (all with MUS) without surgery for prolapse $(n=658)$; for prolapse alone ( $n=1062$, including 888 with at least one mesh); and combined MUS and prolapse surgery $(n=153)$ (see Table 1). The associated hysterectomies (total or subtotal) were not counted as procedures to correct prolapse.

Mean age was 62 (29-93) years and mean BMl $26 \mathrm{~kg} / \mathrm{m}^{2}$ (16-61). Overall, 75.9\% were postmenopausal, $45.9 \%$ sexually active, $9.2 \%$ smokers, and $6.8 \%$ had diabetes. Previous gynaecological history included a hysterectomy $(17.5 \%)$ and surgery for SUI or prolapse (20.4\%). The physical status (ASA score) was rated 1 for 628 women (33.5\%), 2 for $950(50.6 \%), 3$ for $143(7.6 \%)$ and 4 for $2(0.1 \%)$ (see Table 2). Mean length of follow-up was 7.3 months $(0-18)$.

Half the women with isolated SUI treated by MUS underwent a retropubic procedure $(n=338,51.4 \%)$; the others had a transobturator procedure $(n=177)$ or a singleincision sling ( $n=142)$ (data missing for one). MUS was combined with prolapse surgery for 153 women: 76 laparoscopic mesh sacropexies, 7 laparoscopic mesh rectopexies (3 rectopexies were associated with a sacropexy), 34 transvaginal mesh and 39 vaginal native tissue repairs; the MUS placement was retropubic for 67 women, transobturator for 64 , and a single-incision for 16 (six missing data).

The vaginal native tissue repair group included 17 obliterative procedures (colpocleises). The laparoscopy mesh group included 490 sacropexies (sacrohysteropexy or sacrocolpopexy), 91 rectopexies (55 associated with a sacropexy), and 5 other laparoscopic mesh procedures; a single mesh was implanted in the vesicovaginal space in 161 women, in the rectovaginal space in 47 , and a double mesh in both for 316 (seven missing data); in the laparoscopy mesh group, the mesh procedure was combined with a laparoscopic Burch colposuspension 38 times, a subtotal hysterectomy 217 times, a total hysterectomy 11 times, and a vaginal amputation of the uteri cervix twice.

The surgeons reported 63 intraoperative surgical injuries (3.4\%) including 34 of the bladder, 2 of the urethra, 2 of the rectum, and 19 accidental openings of the vagina. In most (all but eight) cases, these injuries did not lead to discontinuation of mesh implantation or MUS placement and were not counted as serious complications. In one case, the inaccessibility of the sacral promontory required conversion of the planned laparoscopic sacropexy to vaginal placement of a subvesical mesh (not considered a serious complication).

Among the 1873 women included in this analysis, $52(2.8 \%)$ experienced a serious complication during the surgery or its first months of follow-up (Table 3); 31 complications were related to a MUS, 4 to a vaginal native tissue repair, 12 to a transvaginal mesh, and 5 to a laparoscopy with mesh. As Figure 1 shows, the incidence of serious complication six months after the procedure was estimated around 3.5\% (95\% Cl 2.0-5.0) after MUS alone (red curve), 7.0\% (2.8-11.3) after 
MUS associated with surgery for prolapse (green curve), 1.7\% (0.0-3.8) for vaginal native tissue repair (grey curve), 2.8\% (0.9-4.6) after transvaginal mesh (orange curve) and $1.0 \%(0.1-1.8)$ after laparoscopy with mesh (blue curve).

Most of these complications were graded IIIb (surgical revision under general anaesthesia), one case required intensive care, and no deaths occurred. The most frequent complication was obstructed micturition (18 cases all related to MUS, $2.2 \%$ ) mesh, 1.3\%; and 2 to laparoscopic mesh, 0.3\%).

Of the 31 complications (3.8\%, 2.7-5.3) related to MUS surgery, 5 occurred during and 1 complete urinary retention. Placement of the MUS was stopped or it was removed four times because of the complication (three injuries and one intraoperative haemorrhage); in the last case, the sling was loosened vaginally on day 1 (Table 4). There were 17 complications treated from two days to two months after the initial intervention: obstructed micturition resulted in loosening the sling in 12 women and dividing it in 2; 1 woman needed to return to the operative room (OR) to evacuate a suburethral thrombus that had resulted in obstructed micturition; and a part of the MUS had to be removed in 2 women because of early vaginal exposure (associated with pain in one case). Between 2 and 12 postoperative months, 9 complications were managed, due to 1 late urinary retention, 5 vaginal MUS exposures (1 with pain), 2 urethral MUS exposures (1 with pain), and 1 painful subcutaneous tumefaction of an incision opening after a retropubic MUS. These complications required MUS division (one case), partial removal of the MUS (seven cases), and vaginal trimming without MUS resection (one case). The risk of MUS complication was higher in women with concomitant POP surgery (Figure 1), but not statistically significantly (aOR 2.12, 95\% Cl 0.88-5.12) (Table S2).

There were 21 complications related to POP surgery (1.7\%, 1.1-2.6). Among them, 8 occurred during surgery or in the first 48 hours: 5 bladder injuries, and 3 haemorrhages (Table 4). Placement of the transvaginal mesh (or concomitant MUS) was stopped or it was removed four times; three haemorrhages required return to the OR for secondary haemostasis (two vaginal native tissue repairs and one transvaginal mesh for a woman who also required a blood transfusion and intensive care); a transvaginal mesh was removed vaginally on day 1 because of bladder exposure discovered during an early reoperation indicated for pain and obstructed micturition. Seven more complications were treated at two days to two months after the initial intervention: in three cases (one laparoscopic sacrohysteropexy and two transvaginal mesh procedures), painful ureteral obstruction was treated with a double-J stent or nephrostomy; in two others, the patient needed to return to the OR to evacuate a haematoma or restore haemostasis (one bleeding after vaginal amputation of the uteri cervix associated with a laparoscopic sacrocolpopexy, and one painful subvesical haematoma after vaginal native tissue repair); in two more cases, the mesh was removed laparoscopically because of a pelvic abscess (one after a laparoscopic sacrocolpopexy and one after a laparoscopic rectopexy). Six vaginal mesh exposures were managed between 2 and 12 postoperative months, four transvaginal placements (one with pain) and two laparoscopic sacrocolpopexies (among women with a previous hysterectomy). These complications required partial removal of the mesh (one transvaginal mesh and two laparoscopic) in three cases, while the other three required vaginal trimming of a transvaginally placed vaginal mesh without resection (Table 4). The risk of a POP surgery complication was lower 
in women with laparoscopic procedures (aOR $0.67,95 \% \mathrm{Cl} 0.16-2.80$ ) and higher for transvaginal mesh placement (aOR 2.18, 0.5-6.22) than for vaginal native tissue repair (Figure 1), but these differences were not statistically significant (Table S3).

Management of complications in seven women necessitated multiple procedures. In 3 of 13 cases, loosening the sling was not sufficient to improve micturition; return to the OR was needed to divide the MUS (1 case) or remove its suburethral portion (2 cases). In two of the cases requiring return to the OR for haemostatic surgery, a second return was necessary, in one case for consolidation and in another to remove the haemostatic compresses. In the sixth case, the placement of a double-J stent, due to urethral blockage after sacrohysteropexy, was completed secondarily by a laparoscopic urethral release. In the seventh, the nephrostomy was replaced by a double-J stent.

Of 811 MUS placed, 11 were removed, in part or totally $(1.4 \%, 0.7-2.3)$, as were 2 of the 391 transvaginal meshes $(0.5 \%, 0.1-1.6)$ and 4 of the 611 meshes placed laparoscopically $(0.7 \%, 0.2-1.5)$.

We also observed 29 surgical revisions $(1.6 \%)$ for recurrent SUI $(n=24)$ or POP $(n=5)$. The most frequent revision was MUS placement after laparoscopic sacropexy $(n=14,3.6 \%)$. Finally, 70 women (3.7\%) underwent at least one subsequent reoperation for serious complications or recurrent SUI or POP (Table 3). 


\section{Main findings}

In the first months after surgery, we observed an incidence of serious complications of $2.8 \%-3.8 \%$ for MUS procedures and $1.7 \%$ for POP procedures. The type of complication differs according to type of and time since surgery. Intraoperative complications were principally intraoperative bladder injuries during vaginal surgery that led to discontinuation of the mesh or sling placement. Half of the early complications were for difficulties in bladder voiding after MUS. The later complications were mainly vaginal exposure of either MUS or mesh, whether they had been placed vaginally or less often, by laparoscopy. The most frequent complications occurred in surgery combining MUS and prolapse repair.

Strengths and limitations

The number of complications reported in this early short-term analysis is too low to enable a powerful explanatory analysis according to the characteristics of the woman, the mesh, the combination of surgical procedures, the surgeon or the centre. For example, the risk of complication appeared higher in combined MUS and POP procedures and in cases of transvaginal mesh placement, but these differences were not statistically significant. Our short-term follow-up does not yet allow us to estimate the long-term incidence of mesh removal for mesh-related pain, which appear to occur most frequently after an interval of two years. ${ }^{17}$

VIGI-MESH was designed to obtain a complete overview of daily practice and help to draw conclusions about the harm-benefit ratio of mesh procedures. The prospective nature of our registry makes it possible to capture a large proportion of eligible surgeries. The quality of the information collected is ensured by cross-checking pharmacy dispensing data and surgical procedure codes. The hospital data systems allow medical events after surgery to be chained and monitored so that complications are not missed.

\section{Interpretation}

Our early results concerning the incidence of complications are similar to those of other recent work. We observed 6 grade III complications after 531 mesh laparoscopies (1.1\%), compared with the PROSPERE trial, where we found only one among 129 laparoscopies (0.8\%). We observed 11 MUS excisions among 811 placed (1.4\%) while a large retrospective English study found an excision rate of $1.4 \%$ at one year. ${ }^{18}$

In our first results, the mesh was removed for pain seven times. In a series of transvaginal mesh-related complications, half were symptomatic before eight months. ${ }^{19}$ Another study with a five-year follow-up showed that more than half the transvaginal mesh-related complications took place during the first year..$^{20}$ It will be necessary to continue the monitoring to identify the incidence of late complications. It would also be useful to be able to specify if these surgeries lead to chronic pain as sequelae. One limitation of the Clavien-Dindo classification is that it does not consider chronic pain. We plan to work with patients on developing a survey about sequelae and chronic pain among the women in this registry.

If we suppose that expert centres have fewer complications, using only such centres for the registry may result in underestimating the risk of complications in everyday practice. On the other hand, the expert centres are probably more likely to diagnose 
these complications early, which may raise their rates of early incidence. We assume that the risk of loss to follow-up, because of disappointment with initial care, should be low in the participating hospitals, because of their experience and ability to identify complications early.

Several additional surgical procedures classified here as serious complications were related to sling adjustments (its loosening or division). One of the advantages of MUS for the treatment of incontinence is precisely the possibility of subsequent adjustment of the sling, which is not possible for other surgical procedures for SUI (retropubic colposuspension or traditional sling). Around 30000 midurethral slings are placed annually in France. ${ }^{21}$ The number of surgical revisions seen in our registry in the early months after the placement of MUS alone was around $3.8 \%$ and may thus indicate that there are around 1100 reoperations for this procedure each year in France. Note that in our registry half the MUS were retropubic, although in France in 2017 (data from the Agence Technique de l'Information sur l'Hospitalisation) this pathway accounted for only $20 \%$ of the MUS placed.

It seems essential to continue long-term monitoring after surgical pelvic floor repair, whether or not mesh is used, to ensure comparison and follow changes in practice as women and surgeons' opinions of mesh evolves. ${ }^{11}$ The registry will allow us to compare the different types of materials and the different methods of placement, to identify those that could present problems and to propose guidelines for the prevention and management of these complications and their sequelae. ${ }^{22}$ Answers to these questions interest clinicians, women, manufacturers, and the public health authorities.

\section{Conclusions}

Short-term serious complications are rare after surgery for urinary incontinence or pelvic organ prolapse, even with mesh use. Monitoring must be continued and enlarged to assess more exactly the long-term risk associated with mesh use and identify the associated risk factors. 


\section{Acknowledgements}

The authors thank the VIGI-MESH team, Lucie Merlet, Florence Tartarin, Elodie Migault, and Pierre-Jean Saulnier; and Jo Ann Cahn for editing.

We thank also all the surgeons who contributed cases to the registry: $A$. Aboukassem, C. Akladios, E. Arsene, S. Aucouturier, E. Bailly, J-J. Baldauf, G. Bader, S. Bartolo, M-L. Barussaud, F. Béchard, K. Ben Naoum, S. Bernardeau, R. Boohdun, T. Boisramé, F. Borie, R. Botchorichvili, M. Boukaram, A. Brams, C. Bruhat, S. Campagne-Loiseau, C. Carlier-Guérin, O. Celhay, T. Charles, A. Charvériat, P. Chauvet, A. Chevrot, P. Collinet, M. Cosson, P. Costa, S. Curinier, P. Debodinance, X. Deffieux, P-O. Delpech, P. Delporte, A. Dubois, E. Faller, B. Fatton, A. Fauconnier, P. Ferry, X. Fritel, P. Gadonneix, O. Garbin, F. Genty, P. Gres, N. Guilhen, M. Guandalino, L. Guy, G. Giraudet, A. Hedde, A. Host, M. Hummel, A. Kane, S. Le Gouic, I. Le Teuff, G. Lebreton, G. Léon, L. Lecointre, J-P. Lucot, L. Martin, A. Marx, P. Mouracade, E. Nkounkou, C. Petitnicolas, A-C. Pizzoferrato, P. Pillot, J-L. Pouly, M. Prudhomme, B. Rabishong, J. Ripoche, G. Rivaux, J. Salerno, D. Salet-Lizee, R. Sarfati, M. Sarradin, C. Saussine, E. Schuller. A. Segaert, N. Siegler, F. Stoll, R. de Tayrac, Y. Thirouard, C. Trichot, S. Trolliet, M. Turck, F. D. Vanderdriessche, Viala, S. Vieillefosse, D. Vinatier, E. Vincens, M. Vinchant, B. Vinson-Bonnet, L. Wagner, S. Wapler, S. Warenbourg.

\section{Disclosure of interest}

XF, SCL, CS, DSL, MLB, TB, CCG, TC, XD, PD, ACP, SC, SR, VR, and AF have no direct or indirect commercial financial incentive associated with publishing the article.

MC, JPL and RdT have received honoraria from Boston Scientific. MC, PF, JPL and RdT have received honoraria from Coloplast.

Contribution to Authorship

$\mathrm{XF}, \mathrm{SCL}, \mathrm{MC}, \mathrm{PF}, \mathrm{CS}, \mathrm{JPL}$, DSL, MLB, TB, CG, TC, PD, XD, ACP, SC, RdT and AF included women, collected and completed data. XF, SR, VR, and AF contributed to the conception, design, analysis, interpretation of data and article writing. Each author had access to the data analysis, participated in revising the manuscript and approved the final submitted version.

\section{Details of Ethics Approval}

Our study complies with French law. The Institutional Review Board (Comité de Protection des Personnes Ouest III) approved the protocol 9 February 2017 (IDRBC 2017-A000308-45), and the study was registered by the national data protection authority (Commission Nationale Informatique et Libertés, CNIL) on 16 August, 2017 (DR-2017-245).

\section{Funding}

The national medicines agency (Agence Nationale de Sécurité du Médicament et des produits de santé, ANSM) provided funding for the study, but played no role in data collection or analysis, assessment of the complications, or interpretation of the results. 
1 Fritel X, Panjo H, Varnoux N, Ringa V. The individual determinants of care-seeking among middle-aged women reporting urinary incontinence: Analysis of a 2273-woman cohort. Neurourol Urodyn 2014;33:1116-22

2 Fritel X, Varnoux N, Zins M, Bréart G, Ringa V. Symptomatic pelvic organ prolapse at midlife, quality of life, and risk factors. Obstet Gynecol 2009;113:609-16

3 Baessler K, Christmann-Schmid C, Maher C, Haya N, Crawford TJ, Brown J. Surgery for women with pelvic organ prolapse with or without stress urinary incontinence. Cochrane Database Syst Rev 2018;8:CD013108.

4 Lucot JP, Cosson M, Bader G, Debodinance P, Akladios C, Salet-Lizée D, et al. Safety of vaginal mesh surgery versus laparoscopic mesh sacropexy for cystocele repair: results of the Prosthetic Pelvic Floor Repair randomized controlled trial. Eur Urol 2018;74:167-76

5 Le Normand L, Cosson M, Cour F, Deffieux X, Donon L, Ferry P, et al. Clinical Practice Guidelines: Synthesis of the guidelines for the surgical treatment of primary pelvic organ prolapse in women by the AFU, CNGOF, SIFUD-PP, SNFCP, and SCGP. J Gynecol Obstet Hum Reprod 2017;46:387-91 Afssaps 2005. Bandelettes posées par voie vaginale, Rapport d'enquête. Available from: http://ansm.sante.fr/var/ansm site/storage/original/application/5c67f2cb300d639de8df75f696e848e a.pdf

7 Sarreau M, Bon D, Estrade V, Villemonteix $P$, Fritel $X$. Sexualité après cure d'incontinence urinaire par bandelette sous-urétrale transobturatrice et satisfaction des patientes [Sexual function after transobturator tape procedure for stress urinary incontinence and overall patients' satisfaction]. Prog Urol 2016;26:24-33 MRHA 2014. A summary of the evidence on the benefits and risks of vaginal mesh implants. Available from:

https://www.gov.uk/government/uploads/system/uploads/attachment data/file/402162/Summary o f the evidence on the benefits and risks of vaginal mesh implants.pdf

9 Khanuengkitkong S, Lo TS, Dass AK. Delayed vaginal and urethral mesh exposure: 10 years after TVT surgery. Int Urogynecol J 2013;24:519-21

10 Roth TM, Reight I. Laparoscopic mesh explantation and drainage of sacral abscess remote from transvaginal excision of exposed sacral colpopexy mesh. Int Urogynecol J 2012;23:953-5 NHS Recommendations of the Mesh Pause Clinical Advisory Group to Medical Directors and Surgical Teams. Available from:

https://www.baus.org.uk/ userfiles/pages/files/Patients/CAGmesh\%20FINAL.pdf

Utilisation des données d'un registre de chirurgie de l'incontinence et du prolapsus pour suivre les dispositifs médicaux concernés faisant partie du programme 2016 de surveillance renforcée des Dispositifs médicaux. Available from:

https://ansm.sante.fr/var/ansm site/storage/original/application/17ae0787d2339be6aba55cba02353 ece.pdf

, Freeman RM, Swift SE, Cosson M, Davila GW, Deprest J, et al. An Internationa Urogynecological Association (IUGA)/International Continence Society (ICS) joint terminology and classification of the complications related directly to the insertion of prostheses (meshes, implants, tapes) and grafts in female pelvic floor surgery. Neurourol Urodyn 2011;30:2-12. Haylen BT, Freeman RM, Lee J, Swift SE, Cosson M, Deprest J, et al. International Urogynecological Association (IUGA)/International Continence Society (ICS) joint terminology and classification of the complications related to native tissue female pelvic floor surgery. Neurourol Urodyn 2012;31:406-14. Fritel X, Campagne-Loiseau S, de Tayrac R, Ferry P, Saussine C, Garbin O, et al. French observatory of pelvic floor repair surgery (with or without mesh), VIGI-MESH, first results after more than 1000 inclusions. IUGA 2018, Vienna. Available from: https://iugameeting.org/2018meeting/program/?where person $=44$

17 Wang C, Christie AL, Zimmern PE. Synthetic mid-urethral sling complications: Evolution of presenting symptoms over time. Neurourology and Urodynamics 2018;37:1937-42

18 Gurol-Urganci I, Geary RS, Mamza JB, Duckett J, El-Hamamsy D, Dolan L, et al. Long-term rate of mesh sling removal following midurethral mesh sling insertion among women with stress urinary incontinence. JAMA 2018;320:1659-69. 
19 Tunitsky E, Abbott S, Barber MD. Interrater reliability of the Inter-national Continence Society and International Urogynecological Association (ICS/IUGA) classification system for mesh-related complications. Am J Obstet Gynecol 2012;206,442.e1-6.

20 Jacquetin B, Hinoul P, Gauld J, Fatton B, Rosenthal C, Clavé H, et al. Total transvaginal mesh (TVM) technique for treatment of pelvic organ prolapse: a 5-year prospective follow-up study. Int Urogynecol J 2013;24:1679-86.

21 Desseauve D, Pierre F, Fritel X. Urinary incontinence in women: study of surgical practice in France. Prog Urol 2013;23:249-55

22 Cundiff GW, Quinlan DJ, van Rensburg JA, Slack M. Foundation for an evidence-informed algorithm for treating pelvic floor mesh complications: a review. BJOG 2018;125:1026-37. 
Figure 1. Survival without serious complication (Kaplan-Meier survival curve) by type of surgical group (MUS alone in red, MUS + POP surgery in green, vaginal native tissue repair in grey,

transvaginal mesh in orange, and laparoscopy with mesh in blue) (MUS: Midurethral sling; POP: pelvic organ prolapse). 
Table 1. Several combinations of surgical procedures in 1873 women.

\begin{tabular}{|c|c|c|c|c|c|c|c|c|c|c|c|c|c|}
\hline \multirow[b]{2}{*}{ Surgical group, N } & \multirow[b]{2}{*}{$\stackrel{\varrho}{\Sigma}$} & \multirow[b]{2}{*}{ 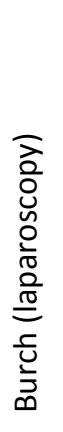 } & \multicolumn{3}{|c|}{$\begin{array}{l}\text { Laparoscopy with } \\
\text { mesh }\end{array}$} & \multicolumn{4}{|c|}{$\begin{array}{c}\text { Vaginal native tissue } \\
\text { repair }\end{array}$} & \multicolumn{3}{|c|}{$\begin{array}{c}\text { Transvaginal } \\
\text { mesh }\end{array}$} & \multirow[b]{2}{*}{ 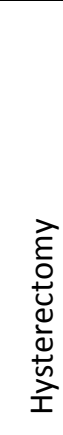 } \\
\hline & & & 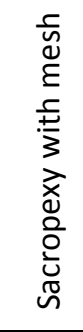 & 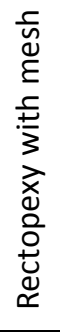 & 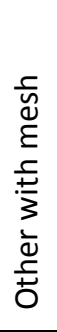 & 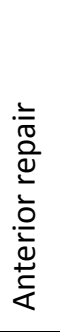 & $\begin{array}{l}\frac{c}{0} \\
\frac{0}{n} \\
\frac{1}{0} \\
\frac{0}{0} \\
\frac{n}{2} \\
\frac{n}{0} \\
\frac{0}{0}\end{array}$ & 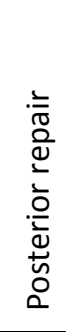 & 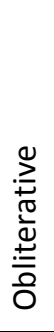 & 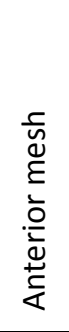 & $\begin{array}{l}\frac{c}{\tilde{d}} \\
\frac{\varepsilon}{\pi} \\
\frac{0}{0} \\
\frac{0}{4}\end{array}$ & & \\
\hline MUS alone, 658 & 658 & - & - & - & - & - & - & - & - & - & - & - & 10 \\
\hline $\begin{array}{r}\text { MUS + POP surgery, } \\
153\end{array}$ & 153 & - & 76 & 7 & - & 14 & 23 & 45 & - & 28 & 22 & 5 & 37 \\
\hline $\begin{array}{r}\text { Vaginal native tissue } \\
\text { repair, } 174\end{array}$ & - & - & - & - & - & 63 & 106 & 121 & 17 & - & - & - & 67 \\
\hline $\begin{array}{r}\text { Transvaginal mesh, } \\
357\end{array}$ & - & - & - & - & - & 3 & 39 & 126 & - & 324 & 273 & 53 & 33 \\
\hline $\begin{array}{r}\text { Laparoscopy with } \\
\text { mesh, } 531\end{array}$ & - & 38 & 490 & 91 & 5 & - & - & 2 & - & - & - & - & 228 \\
\hline Overall, 1873 & 811 & 38 & 566 & 98 & 5 & 80 & 168 & 294 & 17 & 352 & 295 & 58 & 375 \\
\hline
\end{tabular}

MUS: Midurethral sling; POP: pelvic organ prolapse.

Table 2. Characteristics of the women and surgeries included in the analysis $(\mathrm{N}=1873)$

\begin{tabular}{|c|c|c|c|c|c|c|c|c|c|}
\hline 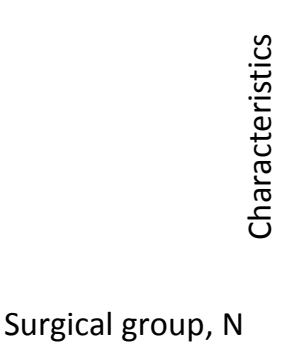 & 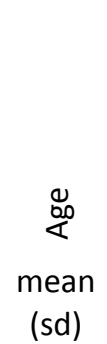 & 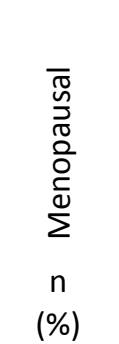 & 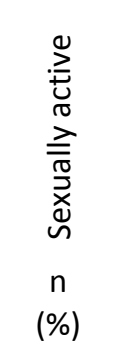 & 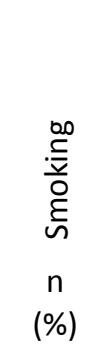 & 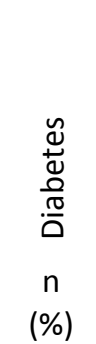 & 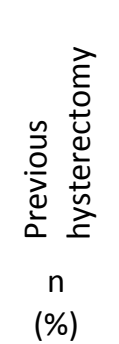 & 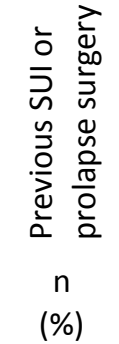 & 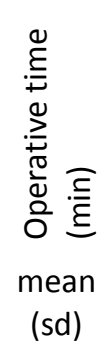 & 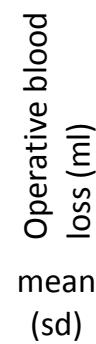 \\
\hline MUS alone, 658 & $\begin{array}{c}57 \\
(13)\end{array}$ & $\begin{array}{c}364 \\
(55.3)\end{array}$ & $\begin{array}{c}367 \\
(55.8)\end{array}$ & $\begin{array}{c}90 \\
(13.7)\end{array}$ & $\begin{array}{c}31 \\
(4.7)\end{array}$ & $\begin{array}{c}98 \\
(14.9)\end{array}$ & $\begin{array}{c}112 \\
(17.0)\end{array}$ & $\begin{array}{c}28 \\
(21)\end{array}$ & $\begin{array}{c}37 \\
(54)\end{array}$ \\
\hline $\begin{array}{r}\text { MUS + POP } \\
\text { surgery, } 153\end{array}$ & $\begin{array}{c}63 \\
(11)\end{array}$ & $\begin{array}{c}121 \\
(79.1)\end{array}$ & $\begin{array}{c}68 \\
(44.4)\end{array}$ & $\begin{array}{c}13 \\
(8.5)\end{array}$ & $\begin{array}{c}8 \\
(5.2)\end{array}$ & $\begin{array}{c}28 \\
(18.3)\end{array}$ & $\begin{array}{c}27 \\
(17.6)\end{array}$ & $\begin{array}{l}139 \\
(73)\end{array}$ & $\begin{array}{c}96 \\
(100)\end{array}$ \\
\hline $\begin{array}{r}\text { Vaginal native } \\
\text { tissue repair, } 174\end{array}$ & $\begin{array}{c}68 \\
(13)\end{array}$ & $\begin{array}{c}151 \\
(86.8)\end{array}$ & $\begin{array}{c}53 \\
(30.5)\end{array}$ & $\begin{array}{c}11 \\
(6.3)\end{array}$ & $\begin{array}{c}17 \\
(9.8)\end{array}$ & $\begin{array}{c}41 \\
(23.6)\end{array}$ & $\begin{array}{c}47 \\
(27.0)\end{array}$ & $\begin{array}{c}80 \\
(40)\end{array}$ & $\begin{array}{c}78 \\
(78)\end{array}$ \\
\hline $\begin{array}{r}\text { Transvaginal mesh, } \\
357\end{array}$ & $\begin{array}{l}70 \\
(7)\end{array}$ & $\begin{array}{c}352 \\
(98.6)\end{array}$ & $\begin{array}{c}103 \\
(28.9)\end{array}$ & $\begin{array}{c}17 \\
(4.8)\end{array}$ & $\begin{array}{c}34 \\
(9.5)\end{array}$ & $\begin{array}{c}78 \\
(21.8)\end{array}$ & $\begin{array}{c}94 \\
(26.3)\end{array}$ & $\begin{array}{c}74 \\
(42)\end{array}$ & $\begin{array}{c}90 \\
(90)\end{array}$ \\
\hline $\begin{array}{r}\text { Laparoscopy with } \\
\text { mesh, } 531\end{array}$ & $\begin{array}{c}62 \\
(10)\end{array}$ & $\begin{array}{c}433 \\
(81.5)\end{array}$ & $\begin{array}{c}270 \\
(50.8)\end{array}$ & $\begin{array}{c}41 \\
(7.7)\end{array}$ & $\begin{array}{c}37 \\
(7.0)\end{array}$ & $\begin{array}{c}81 \\
(15.3)\end{array}$ & $\begin{array}{c}100 \\
(18.8)\end{array}$ & $\begin{array}{l}152 \\
(50)\end{array}$ & $\begin{array}{c}59 \\
(77)\end{array}$ \\
\hline Overall, 1873 & $\begin{array}{c}62 \\
(12)\end{array}$ & $\begin{array}{c}1421 \\
(75.9)\end{array}$ & $\begin{array}{c}861 \\
(46.0)\end{array}$ & $\begin{array}{c}172 \\
(9.2)\end{array}$ & $\begin{array}{c}127 \\
(6.8)\end{array}$ & $\begin{array}{c}326 \\
(17.4)\end{array}$ & $\begin{array}{c}380 \\
(20.3)\end{array}$ & $\begin{array}{c}86 \\
(67)\end{array}$ & $\begin{array}{c}59 \\
(77)\end{array}$ \\
\hline
\end{tabular}

MUS: midurethral sling; POP: pelvic organ prolapse; sd: standard deviation.

Surgical groups differed significantly for age (ANOVA, $\mathrm{p}<0.001)$, menopausal status $\left(\mathrm{Chi}^{2}, P<0.001\right)$, sexual activity $\left(C h i^{2}\right.$, $P<0.001)$, smoking $\left(\mathrm{Chi}^{2}, P<0.001\right)$, diabetes $\left(\mathrm{Chi}^{2}, P=0.01\right)$, previous hysterectomy $\left(\mathrm{Chi}^{2}, P=0.004\right)$, previous SUI or POP surgery $\left(\mathrm{Chi}^{2}, P=0.006\right)$, operative blood loss (ANOVA, $\left.P<0.001\right)$, and operative time (ANOVA, $P<0.001$ ). 
Table 3. Incidence of serious complications (Grade III or more), relapse surgery (for stress urinary incontinence or prolapse), and any subsequent surgical procedure for relapse or complication (intraoperative complications excluded).

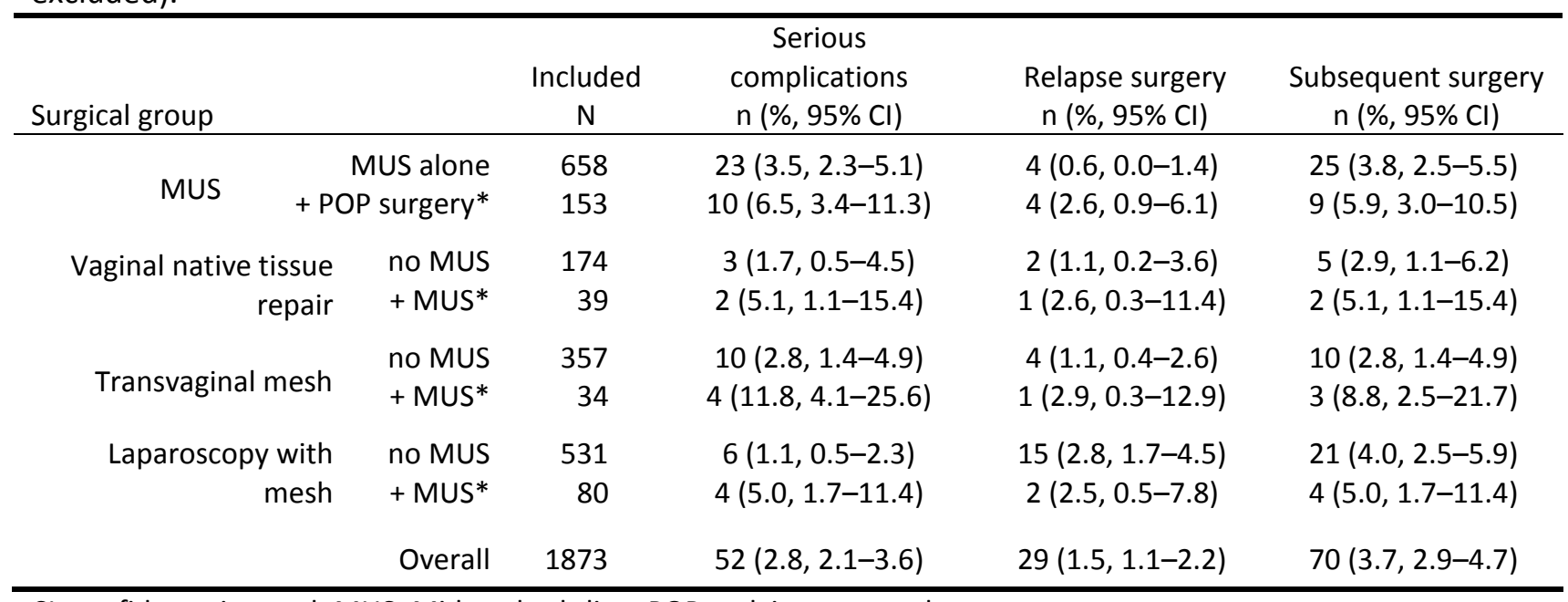

$\mathrm{Cl}$ : confidence interval; MUS: Midurethral sling; POP: pelvic organ prolapse.

*In the group with both MUS and surgery for prolapse, eight complications were related to MUS (incidence: 5.2\%, 2.5-9.6) and two to a transvaginal mesh (incidence: $5.9 \%, 1.2-17.6$ ).

Table 4. Type, timing and management of the serious complications $(N=52)$. The number exceeds 52 because some women had more than one type of complication.

\begin{tabular}{|c|c|c|c|c|c|c|c|c|c|c|c|c|c|c|c|c|c|c|}
\hline \multirow[b]{2}{*}{$\begin{array}{l}\text { Surgical } \\
\text { group }\end{array}$} & \multicolumn{7}{|c|}{ Complication type, n (\%) } & \multicolumn{3}{|c|}{ Time, n (\%) } & \multicolumn{8}{|c|}{ Care for complication, n (\%) } \\
\hline & 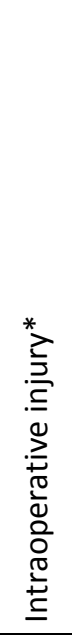 & 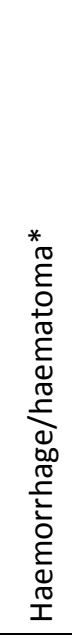 & 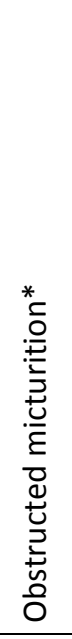 & 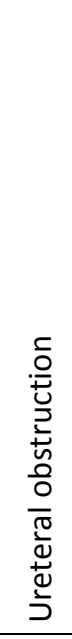 & 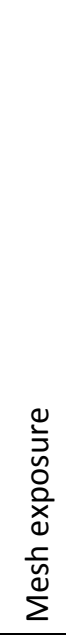 & 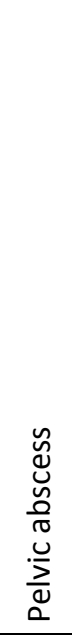 & $\frac{\check{\pi}}{\alpha}$ & 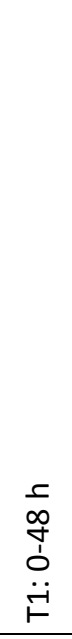 & $\begin{array}{l}\sum_{\dot{1}} \\
\stackrel{\sim}{0} \\
\ddot{N}\end{array}$ & 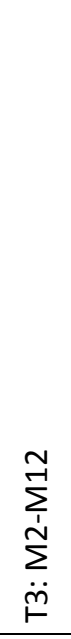 & 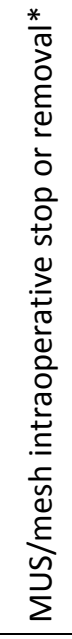 & 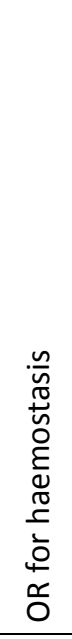 & 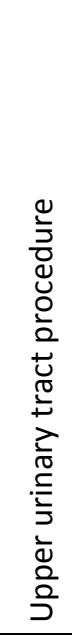 & 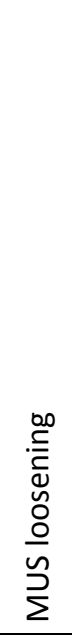 & 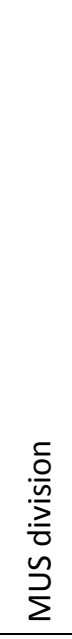 & 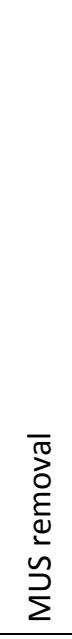 & 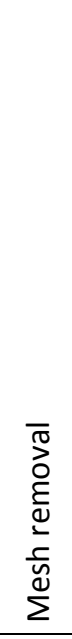 & 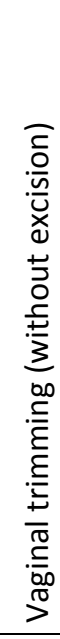 \\
\hline MUS alone & $\begin{array}{c}1 \\
(0.2)\end{array}$ & $\begin{array}{c}1 \\
(0.2)\end{array}$ & $\begin{array}{c}13 \\
(2.0)\end{array}$ & - & $\begin{array}{c}7 \\
(1.1)\end{array}$ & - & $\begin{array}{c}4 \\
(0.6)\end{array}$ & $\begin{array}{c}3 \\
(0.5)\end{array}$ & $\begin{array}{c}12 \\
(1.8)\end{array}$ & $\begin{array}{c}8 \\
(1.2)\end{array}$ & $\begin{array}{c}2 \\
(0.3)\end{array}$ & - & - & $\begin{array}{c}10 \\
(1.5)\end{array}$ & $\begin{array}{c}3 \\
(0.5)\end{array}$ & $\begin{array}{c}7 \\
(1.1)\end{array}$ & - & $\begin{array}{c}1 \\
(0.2)\end{array}$ \\
\hline $\begin{array}{r}\text { MUS + POP } \\
\text { surgery }\end{array}$ & $\begin{array}{c}3 \\
(2.0)\end{array}$ & $\begin{array}{c}1 \\
(0.7)\end{array}$ & $\begin{array}{c}4 \\
(2.6)\end{array}$ & - & $\begin{array}{c}3 \\
(2.0)\end{array}$ & - & $\begin{array}{c}1 \\
(0.7)\end{array}$ & $\begin{array}{c}3 \\
(2.0)\end{array}$ & $\begin{array}{c}5 \\
(3.3)\end{array}$ & $\begin{array}{c}2 \\
(1.3)\end{array}$ & $\begin{array}{c}3 \\
(2.0)\end{array}$ & $\begin{array}{c}1 \\
(0.7)\end{array}$ & - & $\begin{array}{c}3 \\
(2.0)\end{array}$ & - & $\begin{array}{c}2 \\
(1.3)\end{array}$ & - & $\begin{array}{c}1 \\
(0.7)\end{array}$ \\
\hline $\begin{array}{r}\text { Vaginal } \\
\text { native tissue } \\
\text { repair }\end{array}$ & - & $\begin{array}{c}3 \\
(1.7)\end{array}$ & - & - & - & - & $\begin{array}{c}1 \\
(0.6)\end{array}$ & $\begin{array}{c}2 \\
(1.1)\end{array}$ & $\begin{array}{c}1 \\
(0.6)\end{array}$ & - & - & $\begin{array}{c}3 \\
(1.7)\end{array}$ & - & - & - & - & - & - \\
\hline $\begin{array}{r}\text { Transvaginal } \\
\text { mesh }\end{array}$ & $\begin{array}{c}3 \\
(0.8)\end{array}$ & $\begin{array}{c}1 \\
(0.3)\end{array}$ & $\begin{array}{c}1 \\
(0.3)\end{array}$ & $\begin{array}{c}2 \\
(0.6)\end{array}$ & $\begin{array}{c}4 \\
(1.1)\end{array}$ & - & $\begin{array}{c}3 \\
(0.8)\end{array}$ & $\begin{array}{c}5 \\
(1.4)\end{array}$ & $\begin{array}{c}2 \\
(0.6)\end{array}$ & $\begin{array}{c}3 \\
(0.8)\end{array}$ & $\begin{array}{c}3 \\
(0.8)\end{array}$ & $\begin{array}{c}1 \\
(0.3)\end{array}$ & $\begin{array}{c}2 \\
(0.6)\end{array}$ & - & - & - & $\begin{array}{c}2 \\
(0.6)\end{array}$ & $\begin{array}{c}2 \\
(0.6)\end{array}$ \\
\hline $\begin{array}{r}\text { Laparoscopy } \\
\text { with mesh }\end{array}$ & - & $\begin{array}{c}1 \\
(0.2)\end{array}$ & - & $\begin{array}{c}1 \\
(0.2)\end{array}$ & $\begin{array}{c}2 \\
(0.4)\end{array}$ & $\begin{array}{c}2 \\
(0.4)\end{array}$ & $\begin{array}{c}1 \\
(0.2)\end{array}$ & - & $\begin{array}{c}4 \\
(0.8)\end{array}$ & $\begin{array}{c}2 \\
(0.4)\end{array}$ & - & $\begin{array}{c}1 \\
(0.2)\end{array}$ & $\begin{array}{c}1 \\
(0.2)\end{array}$ & - & - & - & $\begin{array}{c}4 \\
(0.8)\end{array}$ & - \\
\hline Overall & $\begin{array}{c}7 \\
(0.4)\end{array}$ & $\begin{array}{c}7 \\
(0.4)\end{array}$ & $\begin{array}{c}18 \\
(1.0)\end{array}$ & $\begin{array}{c}3 \\
(0.2)\end{array}$ & $\begin{array}{l}16 \\
(0.9)\end{array}$ & $\begin{array}{c}2 \\
(0.1)\end{array}$ & $\begin{array}{c}10 \\
(0.5)\end{array}$ & $\begin{array}{c}13 \\
(0.7)\end{array}$ & $\begin{array}{c}24 \\
(1.3)\end{array}$ & $\begin{array}{c}15 \\
(0.8)\end{array}$ & $\begin{array}{c}8 \\
(0.4)\end{array}$ & $\begin{array}{c}6 \\
(0.3)\end{array}$ & $\begin{array}{c}3 \\
(0.2)\end{array}$ & $\begin{array}{c}13 \\
(0.7)\end{array}$ & $\begin{array}{c}3 \\
(0.2)\end{array}$ & $\begin{array}{c}9 \\
(0.5)\end{array}$ & $\begin{array}{c}6 \\
(0.3)\end{array}$ & $\begin{array}{c}4 \\
(0.2)\end{array}$ \\
\hline
\end{tabular}

MUS: midurethral sling; POP: pelvic organ prolapse; OR: operative room.

*The comparison between surgical groups was significant for intraoperative injury $\left(\mathrm{Chi}^{2}, P=0.003\right)$, haemorrhage/haematoma $\left(\mathrm{Chi}{ }^{2}\right.$, $P=0.04)$, obstructed micturition $\left(\mathrm{Chi}^{2}, P<0.001\right)$, and MUS/mesh intraoperative stop or removal $\left(\mathrm{Chi}^{2}, P=0.01\right)$. 